J. Dairy Sci. 101:11480-11480

https://doi.org/10.3168/jds.2018-101-12-11480

(๑) American Dairy Science Association ${ }^{\circledR}, 2018$.

\title{
Corrigendum to "Effects of gradual and later weaning ages when feeding high milk replacer rates on growth, textured starter digestibility, and behavior in Holstein calves from 0 to 4 months of age" (J. Dairy Sci. 101:9863-9875)
}

T. S. Dennis, F. X. Suarez-Mena, T. M. Hill, J. D. Quigley, R. L. Schlotterbeck, R. N. Klopp, G. J. Lascano, and L. Hulbert

In Table 1, on page 9867, the starter CP value should be 20.5 (not 5.0); the corrected table is shown below (corrected value in bold).

The authors regret the errors.

Table 1. Analyses of feeds used in the current study

\begin{tabular}{lcrr}
\hline Nutrient $^{1}$ & MR $^{2}$ & Starter $^{3}$ & Hay \\
\hline DM, \% as-fed & 96.5 & 88.1 & 85.4 \\
CP & 25.0 & $\mathbf{2 0 . 5}$ & 6.0 \\
ADF & - & 7.7 & 40.8 \\
NDF & - & 17.2 & 63.5 \\
Sugar & - & 6.0 & 11.3 \\
Starch & - & 39.7 & 0.9 \\
Fat & 17.8 & 3.9 & 1.8 \\
Ash & 5.7 & 6.6 & 7.2 \\
ME ${ }^{4}$ Mcal/kg & 4.6 & 3.1 & 2.2 \\
\hline
\end{tabular}

${ }^{1}$ Percent of DM unless otherwise stated.

${ }^{2}$ Milk replacer manufactured from whey, whey protein concentrate, and animal fat.

${ }^{3} 37 \%$ whole corn, $35 \%$ protein/mineral pellet, $25 \%$ whole oats, and $3 \%$

liquid molasses.

${ }^{4}$ Metabolizable energy calculated using NRC (2001) equations.

\section{REFERENCES}

Dennis, T. S., F. X. Suarez-Mena, T. M. Hill, J. D. Quigley, R. L. Schlotterbeck, R. N. Klopp, G. J. Lascano, and L. Hulbert. 2018. Effects of gradual and later weaning ages when feeding high milk replacer rates on growth, textured starter digestibility, and behavior in Holstein calves from 0 to 4 months of age. J. Dairy Sci. 101(11):9863-9875. https://doi.org/10.3168/jds.2018-15319. 